\title{
DIALOG PEMIKIRAN TENTANG NORMA RIBA, BUNGA BANK, DAN BAGI HASIL DI KALANGAN ULAMA
}

\author{
Hisam Ahyani' ${ }^{1}$, Dian Permana2, Agus Yosep Abduloh ${ }^{3}$ \\ ${ }^{1}$ Sekolah Tinggi Agama Islam Miftahul Huda Al Azhar Banjar, Jawa Barat \\ Email : hisamahyani@gmail.com \\ ${ }^{2}$ Sekolah Tinggi Agama Islam Miftahul Huda Al Azhar Banjar, Jawa Barat \\ Email : dianpermana128@gmail.com \\ ${ }^{3}$ Sekolah Tinggi Agama Islam Miftahul Ulum Tasikmalaya, Jawa Barat \\ Email: agusyosepabd01@ gmail.com
}

\begin{abstract}
This research found that the Norma of Riba in Islamic Economics is a khilafiyah problem as well as the law of Bank Interest, in principle, mutual tolerance and mutual respect and respect for inter-opinions must be put forward. This is because each group of ulama has devoted their energy to seeking the law of the problem, and in the end their opinion remains different. Profit sharing norms in Islamic economics are an innovative step in an Islamic economy that is not only in accordance with people's behavior, but more than that profit sharing is a social balance step in obtaining economic opportunities. Thus, the profit sharing system can be seen as a more effective measure to prevent conflict between the rich and the poor from occurring in social life. The impact of Bank Interest (Riba) on the Country's Economy, among others, has an impact on several sectors including the Economic Impact. The higher the interest rate, the higher the price to be set on an item. Social Impact, the social impact of society related to Riba in terms of unfair income. Impact of Company Resilience, only companies that have resilience will survive.
\end{abstract}

Keywords: Bank Interest, Riba, Profit Sharing, Economic Impacts in Indonesia.

Abstrak: Penelitian ini ditemukan bahwa Norma Riba dalam Ekonomi Islam merupakan masalah khilafiyah begitupun hukum Bunga Bank pada prinsipnya saling toleransi dan saling menghormati serta menghargai antar pendapat harus dikedepankan. Sebab, masing-masing kelompok ulama telah mencurahkan tenaga dalam berijtihad menemukan hukum masalah tersebut, dan pada akhirnya pendapat mereka tetap berbeda. Norma bagi hasil dalam Ekonomi Islam suatu langkah inovatif dalam ekonomi Islam yang tidak hanya sesuai dengan perilaku masyarakat, namun lebih dari itu bagi hasil merupakan suatu langkah keseimbangan sosial dalam memperoleh kesempatan ekonomi. Dengan demikian, sistem bagi hasil dapat dipandang sebagai langkah yang lebih efektif untuk mencegah terjainya konflik kesenjangan antara yang kaya dan si miskin di dalam kehidupan bermasyarakat. Dampak Bunga Bank (Riba) terhadap Perekonomian Negara diantaranya berdampak dari terhadap beberapa sector diantaranya Dampak Ekonomi, Semakin tinggi suku bunga, semakin tinggi pula harga yang akan ditetapkan pada suatu barang. Dampak Sosial Kemasyarakatan, dampak social masyarakat terkait Riba dalam hal pendapatan yang didapatkan secara tidak adil. Dampak Ketahanan Perusahaan, hanya perusahaan yang punya daya ketahananlah yang akan tetap bertahan.

Kata kunci: Bunga Bank, Riba, Bagi Hasil, Dampak Perekonomian di Indonesia. 
Pembangunan nasional dalam bidang hukum merupakan tugas berat bangsa Indonesia yang menuntut semua pihak untuk mendukungnya.Hal ini dikarenakan bahwa konsep-konsep hukum yang ada di Indonesia masih banyak diwarisi oleh hukum kolonial, dan masyarakat yang silih berganti terus mengalami perberkembang. Hal inilah yang mengharuskan pengkajian secara continue apakah hukum yang ada sekarang ini masih relevan dengan kondisi zaman dan masyarakat sekarang ini. Ketidakpatuhan masyarakat pada suatu hukum disebabkan salahsatunya adalah masyaraakat menganggap bahwa hukum yang berlaku itu sudah tidak memenuhi kebutuhan masyarakat. Salah satu contohnya adalah bahwa banyak ulama' yang berpendapat bahwa bunga bank adalah riba dan riba adalah kharam. Namun tidak demikian halnya dengan sikap masyarakat. Walaupun banyak ulama dan bahkan fatwa MUI menegaskan bahwa bunga bank adalah riba dan riba adalah kharam namun fakta dilapangan masih banyak kita dapatkan umat Islam yang banyak menggunakan bank konvensional sebagai tempat bertransaksi walau sudah dijelaskan bahwa bunga bank konvensional itu riba dan riba itu haram.

Model daripada Ekonomi Syariah yang dibangun atas dasar filosofi religiusitas, dan institusi keadilan dan juga instrumen kemaslahatan sebagaimana dalam surat altakatsur 1-2:

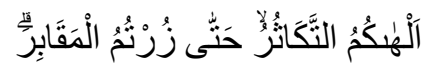

\section{Bermegah-megahan telah melalaikan kamu, sampai kamu masuk ke dalam} kubur. ${ }^{I}$

Perspektif Alquran mengenai pembahasan hukum riba dijelaskan pertama yaitu Qur'an Surat Arrum ayat 39 yang artinya : "Dan sesuatu riba yang kamu lakukan agar menambah harta manusia, maka riba itu tidak menambah disisi Allah. Dan apa yang kamu berikan berupa zakat yang kamu maksudkan untuk mencari keridloan Allah, maka orang-orang yang berbuat demikian adalah arang-orang yang melipatgandakan pahalanya".

Kedua, Qur'an Surat Annisa' ayat 161 yang artinya : “Dan karena mereka mengambil riba, padahal mereka dilarang mengambilnya dan karena memakan harta orang dengan jalan yang bathil. Kami sediakan untuk orang-orang kafir itu siksaan yang pedih".

Ketiga adalah ayat Ali Imran ayat 130 yang artinya : "Hai orang-orang yang beriman, janganlah kamu memakan riba dengan berlipat ganda dan bertakwalah kamu kepada Allah supayan kamu mendapat kemenangan." Ayat tentang riba yang terakhir turun adalah Qur'an Surat Albaqarah ayat 275 yang artinya "Orang yang makan riba tidak dapat berdiri melainkan seperti berdirinya orang yang kemasukan setan lantaran penyakit jiwa. Dan jika kamu bertaubat (dari pengambilan riba), maka bagimu hartamu, kamu tidak menganiyaya dan tidak pula dianiaya".

1 Tafsir Ringkas Kemenag (Ayat 1 Al-Takatsur) dijelaskan bahwa Wahai manusia, bermegah-megahan dalam hal harta, keturunan, dan pengikut telah melalaikan kamu dari ketaatan kepada Allah dan mempersiapkan diri untuk menghadapi hari akhir.

Tafsir Kemenag (Ayat 2 Al-Takatsur) Allah menjelaskan keadaan bermegah-megah di antara manusia atau dengan usaha untuk memiliki lebih banyak dari orang lain akan terus berlanjut hingga mereka masuk lubang kubur. Dengan demikian, mereka telah menyia-nyiakan umur untuk hal yang tidak berfaedah, baik dalam hidup di dunia maupun untuk kehidupan akhirat. Para ulama berpendapat bahwa menziarahi kuburan adalah obat penawar yang paling ampuh untuk melunakkan hati, karena dengan ziarah kubur itu manusia akan ingat mati dan hari akhirat, maka dengan sendirinya akan membatasi keinginan-keinginan yang bukan-bukan. Nabi Muhammad bersabda: Saya pernah melarang kamu menziarahi kubur, maka sekarang ziarahilah kubur itu, karena menziarahi kubur itu akan menjadikan zuhud dari kemewahan dunia dan mengingatkan kamu kepada kehidupan akhirat. (Riwayat Ibnu Majah dari Ibnu Mas'ud). Diakses dari quran.kemenag.go.id, Oktober 2020

${ }_{2}^{2}$ Memahami Asbabun Nuzul Ayat-ayat riba sangat penting sekali sebab ketetapan Alquran hanya dapat kita pahami melalui pengetahuan mengenai kondisi dan situasi sebab turunnya ayat. Jika di ikuti pendapat ahli tafsir 


\section{RUMUSAN MASALAH}

Dari latarbelakang di atas penulis mengajukan beberapa pertanyaan penelitian meliputi pertama, Bagaimana Konsep dalam Norma Riba, Bunga Bank, dan Bagi Hasil di Kalangan Ulama ?; kedua, Bagaimana perbandingan antara sistem bagi hasil pada perbankan syari'ah dengan sistem bunga pada perbankan konvensional perspektif Ulama dulu dan sekarang ?; ketiga, bagaimana Dampak Bunga Bank (Riba) terhadap Perekonomian Negara?.

\section{METODE}

Jenis penelitian ini termasuk dalam kategori penelitian hukum yang bersifat normatif. Metode yang digunakan dalam penelitian ini adalah penelitian kepustakaan, dengan metodologi penelitian kualitatif, menggunakan pendekatan perundang-undangan, pendekatan historis, pendekatan komparatif dan pendekatan konseptual.

\section{HASIL DAN PEMBAHASAN}

\section{Norma Riba}

Beberapa ahli hukum menganggap kata norma merupakan sinonim dengan kata kaidah. Tetapi jika ditinjau dari kamus bahasa Indonesia maka kedua kata tersebut memiliki arti yang berlainan namun tetap merujuk pada satu pokok bahasan yakni aturan. Kata norma dalam Kamus Bahasa Indonesia diartikan sebagai aturan atau ketentuan yang mengikat semua atau sebagaian warga masyarakat; aturan yang baku, ukuran untuk menentukan sesuatu. Adapun kata kaidah dalam kamus berarti perumusan asas-asas yang menjadi hukum; aturan tertentu; patokan; dalil (Nasional 2008, 1007). Jika ditinjau dari segi etimologi, kata norma berasal dari bahasa Latin sedangkan kata kaidah berasal dari bahasa Arab. Norma berasal dari kata nomos yang berarti nilai dan kemudian dipersempit maknanya menjadi norma hukum. Sedangkan kaidah dalam bahasa Arab berasal dari kata qo'idah yang berarti ukuran atau nilai pengukur (Asshiddiqie 2011,1).

Perspektif hadist tentang riba perlu dipahami bahwa fungsi daripada hadist selain sebagi sumber hukum Islam yang ke dua hadist juga berfungsi sebagai Penjelas, memerinci dan memperkuat apa yang telah disampaikan pada Alqur'an. Seperti halnya hadist yang disampaikan oleh Rasulullah pada saat haji wada' sebagai berikut (Hadi 1993, 18):

"Ingatlah bahwa kamu akan menghadap Tuhanmu dan Dia pasti akan menghitung amalanmu. Allah telah melarang kamu mengambil riba. Oleh karena itu, utang akibat riba harus dihapuskan. Modal (uang pokok) kamu adalah hak kamu. Kamu tidak akan menderita ataupun mengalami ketidak adilan” (H.R. Bukhori dan Muslim)

Hadist dari Ubadah bin Said, dari Nabi saw, sabdanya :" emas dengan emas perak dengan perak beras dengan beras, gandum dengan gandum, kurma dengan kurma dan garam dengan garam, kalau sama macamnya dan sama bentuknya adalah riba tapi bila

dan riwayat-riwayat mereka tentang sebab-sebab turunnya ayat-ayat ini maka mayoritas mereka dapat diketahui menyatkan bahwa bangsa Arab Jahiliyah biasa melakukan transaksi riba, khususnya kalangan kaya. Memang sudah terjadi transaksi produktif namun secara individual seperti yang terjadi pada bani Tsaqif. Merupakan hal yang tidak terpuji kalau orang kaya memanfaatkan kesempitan orang miskin untuk memungut Riba. Dengan demikian yang menjadi Illat Hukum dari kharamnya riba adalah karena penindasan. 
berlainan jenisnya maka lakukanlah jual beli jika kamu menghendakinya selama dengan kontan", (H.R. Muslim) Yang ke tiga Hadist dari ubadah bin Yazid, bahwa ia mendengar Ibnu Abbas berkata :'Usamah bin Zaid telah meriwayatkan kepadaku bahwa Nabi saw bersabda :"Riba hanya pada hutang". (H.R. Muslim). Berpijak dari ayat-ayat dan hadisthadist istilah riba sangat populer dikalangan umat Islam yang dimaknai dengan sesuatu yang haram. Dilarang oleh agama jika melakukan perbuatan Riba.

Riba perspektif agama-agama samawi dijelaskan sebagai berikut. Orang-orang Yahudi dilarang mempraktikkan pengambilan bunga. Pelarangan ini banyak sekalai terdapat pada kitab suci mereka baik dalam Old Testement ( perjanjian lama) maupun undang-undang talmud. Kitab Exodus (keluaran) pasal 22 ayat 25 menyatakan, "Jika engkau meminjamkan uang kepada salah seorang dari umatku, orang yang miskin diantaramu, maka janganlah engkau berlaku sebagai penagih utang terhadap dia : janganlah engkau bebankan bunga uang terhadapnya (Antonio 2001, 41). Menurut Pendeta St. Augustine berpendapat bahwa pemberlakuan bunga pada orang miskin lebih kejam dibandingkan dengan perampok yang merampok orang kaya. Ini karena duaduanya sama-sama merampok, satu terhadap orang kaya dan lainnya terhadap orang miskin.

Seperti halnya Riba yang dikenal sebagai tambahan yang tidak disertai dengan adanya pertukaran kompensasi ini jelas dilarang oleh al-Qur'an (alArabi 1957, 321). Riba dalam pandangan ulama' khalaf (ulama' modern) Yusuf Qordawi seorang ulama' besar asal mesir yang tinggal di Qatar menjelaskan bahwa soal riba telah tuntas sejak puluhan tahun silam yaitu haram. Begitu juga Muh. Rasyid Ridlo. Walaupun mayoritas ulama' di Era modern ini masih banyak yang mengharamkan riba namun sudah mulai ada pendapat yang berpendapat bahwa bunga bank boleh (Al-Qardhawi 2002, 22).

Al-Razi, al-Shabuni berpendapat bahwa riba adalah tambahan secara mutlak (alShabuni t.t, 383). Demikian pula al-Jurjani dalam kitab al-Ta'rifat menjelaskan bahwa riba secara bahasa bermakna ziyadah atau tambahan (al-Jurjani t.t, 109).

Quraish Shihab berpendapat kata riba dari segi bahasa berarti kelebihan. Kalau kita hanya berhenti pada makna kebahasaan ini, maka logika yang dikemukakan para penentang riba pada masa Nabi dapat dibenarkan. Ketika itu mereka berkata sebagaimana diungkapkan dalam al-Qur'an, bahwa jual beli sama saja dengan riba (QS. al-Baqarah [2]:275), Allah menjawab mereka dengan tegas bahwa "Allah menghalalkan jual beli dan mengharamkan riba". Penegasan ini dikemukakan-Nya tanpa menyebut alasan secara eksplisit, namun dapat dipastikan bahwa tentu ada alasan atau hikmah sehingga riba diharamkan dan jual beli dihalalkan (Shihab 1998, 413).

Abdurrahman -Jaziri dalam Kitab al-Fiqh ala Madzahib al-Arba'ah menjelaskan bahwa riba menurut istilah fuqaha merupakan tambahan pada salah satu dua barang yang sejenis yang ditukar tanpa adanya imbalan atau timbangan terhadap tambahan tersebut (Al-Jaziri t.t, 198). Pandangan madzhab Syafi'i, riba bermakna sebagai transaksi dengan imbalan tertentu yang tidak diketahui kesamaan takarannya maupun ukuran waktunya kapan terjadi transaksi dengan penundaan penyerahan kedua barang yang dipertukarkan atau salah satunya (al-Nawawi t.t, 403).

Bahwa umat Islam Indonesia masih mempertanyakan terkait status hukum bunga (interst/fa'idah) yang dikenakan dalam transaksi pinjaman (al-qardh) atau utang piutang (al-dayn), baik yang dilakukan oleh lembaga keuangan, individu maupun lainnya maka Majelis Ulama Indonesia mengeluatkan fatwa nomor 1 tahun 2004 tentang bunga 
(interest/fa'idah), sebagaimana dirman Allah Swt sebagai berikut dalam Q.S al-Abaqarah ayat $275-276$ :

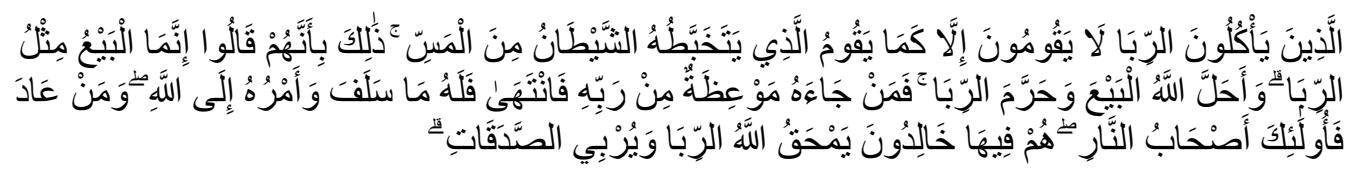

"Orang-orang yang makan (mengambil) riba tidak dapat berdiri melainkan seperti berdirinya orang yang kemasukan syaitan lantaran (tekanan) penyakit gila. Keadaan mereka yang demikian itu, adalah disebabkan mereka berkata (berpendapat), sesungguhnya jual beli itu sama dengan riba, padahal Allah telah menghalalkan jual beli dan mengharamkan riba. Orang-orang yang telah sampai kepadanya larangan dari Tuhannya, lalu terus berhenti (dari mengambil riba), maka baginya apa yang telah diambilnya dahulu (sebelum datang larangan); dan urusannya (terserah) kepada Allah. Orang yang mengulangi (mengambil riba), maka orang itu adalah penghuni-penghuni neraka; mereka kekal di dalamnya. Allah memusnahkan riba dan menyuburkan sedekah. (Q.S al-Abaqarah ayat 275-276).

Hal senada dengan Hadits yang diriwayatkan oleh Imam Muslim dalam kitab Masaqah Halaman 2995 sebagai berikut :

Dari Abdullah r.a., ia berkata: "Rasulullah s.a.w. melaknat orang yang memakan (mengambil) dan memberikan riba." Rawi berkata: saya bertanya: "(apakah Rasulullah melaknat juga) orang yang menuliskan dan dua oarang yang menjadi saksinya?" Ia (Abdullah) menjawab: "kami hanya menceritakan apa yang kami dengar." (HR. Muslim).

Pendapat para ulama ahli fiqh bahwa bunga yang dikenakan dalam transaksi pinjaman (utang-piutang, al-qardh; al-qardh wa al-iqtiradh) telah memenuhi kriteria riba yang diharamkan Allah SWT, seperti dikemukakan, antara lain, oleh Imam Nawawi dalam Al-Majmu' Al-Nawawi berkata Sahabat-sahabat kami (ulama mazhab Syafi'i) berbeda pendapat tentang pengharaman riba yang ditegaskan oleh al-Qur'an, atas dua pandangan.

Pertama, pengharaman tersebut bersifat mujmal (global) yang dijelaskan oleh sunnah. Setiap hukum tentang riba yang dikemukakan oleh sunnah adalah merupakan penjelasan (bayan) terhadap kemujmal-an al-Qur'an, baik riba naqd maupun riba nasi'ah.

Kedua, bahwa pengharaman riba dalam al-Qur'an sesungguhnya hanya mencakup riba nasa' yang dikenal oleh masyarakat Jahiliah dan permintaan tambahan atas harta (piutang) disebabkan penambahan masa (pelunasan). Salah seorang di antara mereka apabila jatuh tempo pembayaran piutangnya dan pihak berutang tidak membayarnya, ia menambahkan piutangnya dan menambahkan pula masa pembayarannya. Hal seperti itu dilakukan lagi pada saat jatuh tempo berikutnya. Itulah maksud firman Allah: “... janganlah kamu memakan riba dengan berlipat ganda...". Kemudian sunnah menambahkan riba dalam pertukaran mata uang (naqd) terhadap bentuk riba yang terdapat al-Qur'an.

Adapun Ibn al-'Araby dalam Ahkam al-Qur'an Riba dalam arti bahasa adalah kelebihan (tambahan). Sedangkan yang dimaksud dengan riba dalam al-Qur'an adalah setiap kelebihan (tambahan) yang tidak ada imbalannya (al-Arabi 1957). Sedang Al-'Aini 
dalam 'Umdah al- Qari' Arti dasar riba adalah kelebihan (tambahan). Sedangkan arti riba dalam hukum Islam (syara') adalah setiap kelebihan (tambahan) pada harta pokok tanpa melalui akad jual beli. Muhammad Abu Zahrah dalam Buhuts fi al-Riba Riba (yang dimaksud dalam) al-Qur'an adalah riba (tambahan, bunga) yang dipraktikkan oleh bank dan masyarakat; dan itu hukumnya haram, tanpa keraguan.

Wahbah al-Zuhaily dalam Al-Fiqh alIslamy wa Adillatuh menjelaskan terkait Bunga bank adalah haram, haram, haram. Riba atau bunga bank adalah riba nasi'ah, baik bunga tersebut rendah maupun berganda. (Hal itu) karena kegiatan utama bank adalah memberikan utang (pinjaman) dan menerima utang (pinjaman). Bahaya (madharat) riba terwujud sempurna (terdapat secara penuh) dalam bunga bank. Bunga bank hukumnya haram, haram, haram, sebagaimana riba. Dosa (karena bertransaksi) bunga sama dengan dosa riba; alasan lain bahwa bunga bank berstatus riba adalah firman Allah SWT.

Dan jika kamu bertaubat (dari pengambilan riba), maka bagimu pokok hartamu... (QS. Al-Baqarah [2]: 279).

Dalam penelitian Tesis Hamim Ilyas, berjudul Riba dalam Muamalah ditemuan bahwa Riba tidak hanya terjadi pada masalah ekonomi saja, tetapi juga terjadi pada sosial. Dari pembagian riba tersebut, maka muncullah pintu-pintu riba, karena semua transaksi komoditas ribawi yang tidak sesuai dengan syarat-syarat yang sudah ditetapkan dan semua perbuatan yang memiliki nilai dan dampak yang sama dengan riba, maka tergolong pintu riba. Riba ekonomi adalah riba yang terjadi pada segala usaha manusia dalam memenuhi kebutuhannya guna mencapai kemakmuran hidupnya. Sedangkan riba sosial adalah istilah yang digunakan untuk pembunuhan karakter, perusakan nama baik, martabat dan harga diri seseorang (Bakar 2018).

\section{Norma Bunga Bank}

Bunga bank adalah termasuk riba, sehingga bunga bank juga diharamkan dalam ajaran Islam. Riba bisa saja terjadi pada pinjaman yang bersifat konsumtif, maupun pinjaman yang bersifat produktif. Dan pada hakikatnya riba dalam bunga bank memberatkan peminjam. Tentang permasalahan riba dari segi hukum dan penafsirannya serta bunga bank dari tinjauan hukum Islam serta menganalisis dampaknya terhadap perekonomian, baik yang dikemukan oleh para pakar hukum Islam, mufassirin dan para ekonom muslim. Ada perbedaan pendapat di antara fuqaha dalam memandang hukum bunga bank dan analisa para pakar terhadap dampaknya yang ditimbulkannya dalam perekonomian umat baik secara mikro maupun makro.

Pendapat jumhur ulama berpendapat bahwa bunga bank tidak boleh (haram) sementara, sebagian ulama diantaranya Abdullah Yusuf Ali dan Muhammad Asad berpendapat bahwa bunga yang diharamkan adalah riba yang berlipat ganda (tidak wajar), sementara bunga yang tidak berlipat ganda boleh, termasuk dalam kategori ini bunga bank yang dipraktekkan pada saat ini. Perbedaan pendapat ini dilatarbelakangi adanya perbedaan penafsiran mufassirin terhadap ayat-ayat tentang riba. Pengharaman riba /usurios dalam Islam berdasarkan pertimbangan-pertimbangan moral dan kemanusiaan sebab esensi pelarangan riba adalah penghapusan segala bentuk praktik ekonomi yang menimbulkan kezaliman dan ketidakadilan. Dan dampak bunga terhadap perekomian akan menyebabkan terhambatnya pertumbuhan ekonomi (Kalsum 2014).

Esensi dasar pelarangan riba dalam Islam adalah menghindari adanya ketidakadilan dan kezaliman dalam segala praktik ekonomi. Sementara riba (bunga) pada hakekatnya adalah pemaksaan suatu tambahan atas debitur yang melarat, yang seharusnya ditolong 
bukan dieksploitasi dan memaksa hasil usaha agar selalu positif. Hal ini bertentangan dengan prinsip ajaran Islam yang sangat peduli dengan kelompok-kelompok sosio-ekonomi yang lebih rendah agar kelompok ini tidak dieksploitasi oleh orang-orang kaya (pemilik dana). Sebab ajaran ekonomi Islam mengemban misi humanisme, tatanan sosial dan menolak adanya ketidakadilan dan kezaliman yang mata rantainya berefek pada kemiskinan.

Sebaliknya sistem ekonomi konvensional yang banyak bahas tidak hanya ekonomekonom muslim tetapi juga tokoh-tokoh non muslim sendiri. Sumber penyebab timbulnya permasalahan kemanusiaan menurut para pakar ekonomi terletak pada sistem ekonomi yang tidak peduli dengan prinsip persamaan (equality), pemerataan (equity), kurangnya mengedepankan kemanusiaan (humanity) serta nilai-nilai agama (religious values). Salah satu penghalang terbesar bagi tercapainya keadilan yang merata (penyebab timbulnya ketidakadilan, inequity) adalah sistem riba (bunga). Jadi mustahil keadilan dapat tercipta tanpa mengeleminasi bunga dari habitat perekonomian dan menegakkan sistem perekonomian yang bebas dari segala macam bentuk riba yang melahirkan model perilaku homo economicus dengan memegang prinsip homo homini lupus, yakni perilaku yang mengebiri dan mengabaikan nilai-nilai moral dan agama serta mementingkan perlindungan atas hak-hak perorangan (utilitarian individualism) sementara mengabaikan kepentingan bersama.

\section{Pendapat Ulama tentang Bunga Bank}

Pendefinisian riba secara teknis menurut para fuqaha yaitu merupakan suatu pengambilan tambahan dari harta pokok atau modal secara batil baik dalam utang piutang maupun jual beli (al-Qurtubi 1981, 128). Batil dalam hal ini merupakan perbuatan ketidakadilan (zalim) atau diam menerima ketidakadilan. Pengambilan tambahan secara batil akan menimbulkan kezaliman di antara para pelaku ekonomi. Dengan demikian esensi pelarangan riba adalah penghapusan ketidakadilan dan penegakan keadilan dalam perekonomian.

Didalam kegiatan bank konvensional ada terdapat dua macam bunga, Pertama bunga simpanan yaitu bunga yang diberikan oleh bank sebagai rangsangan atau balas jasa bagi nasabah yang menyimpan uangnya di bank, seperti jasa giro, bunga tabungan, atau bunga deposito. Bagi pihak bank, bunga simpanan merupakan harga beli. Kedua, bunga pinjaman, yaitu bunga yang dibebankan kepada para peminjam atau harga yang harus dibayar oleh peminjam kepada bank, seperti bunga kredit. Bagi pihak bank, bunga pinjaman merupakan harga jual.

Bunga simpanan dan juga bunga pinjaman merupakan komponen utama faktor biaya dan pendapatan bagi bank. Bunga simpanan adalah biaya dana yang harus dikeluarkan kepada nasabah, sedangkan bunga pinjaman adalah pendapatan yang diterima dari nasabah. Artinya ada Selisih dari bunga pinjaman dikurangi bunga simpanan merupakan laba atau keuntungan yang diterima oleh pihak bank (Muslich 2013, 503). Para ulama kontemporer berbeda pendapat tentang hukum bunga bank. Pertama, sebagian ulama, seperti Yusuf Qaradhawi, Mutawalli Sya'rawi, Abu Zahrah, dan Muhammad al-Ghazali, menyatakan bahwa bunga bank hukumnya haram, karena termasuk riba. Pendapat ini juga merupakan pendapat forum ulama Islam, meliputi: Majma' alFiqh al-Islamy, Majma' Fiqh Rabithah al-'Alam al-Islamy, dan Majelis Ulama Indonesia (MUI).

Adapun dalil diharamkannya riba adalah firman Allah subhanahu wa ta'ala dalam Surat al-Baqarah ayat 275: 


$$
\text { وَأَحَلَّ اللَّهُ الْبَيْعَ وَحَرَّمَ الرِّبَا }
$$

Padahal Allah telah menghalalkan jual beli dan mengharamkan riba.

Dan hadits Nabi Muhammad shallallahu alaihi wasallam yang diriwayatkan oleh Jabir bin Abdillah:

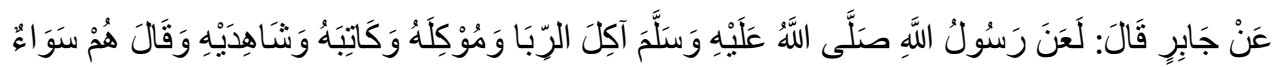

Dari Jabir, ia berkata: "Rasulullah shallallahu 'alaihi wasallam melaknat orang yang memakan (mengambil) riba, memberikan, menuliskan, dan dua orang yang menyaksikannya." Ia berkata: "Mereka berstatus hukum sama." (HR. Muslim, nomor 2994). (Lihat: Yusuf Qaradhawi, Fawa'id al-Bunuk Hiya al-Riba al-Haram, Kairo: Dar al-Shahwah, halaman 5-11; Fatwa MUI Nomor 1 tahun 2004 tentang bunga).

Kedua, sebagian ulama kontemporer lainnya, seperti syaikh Ali Jum'ah, Muhammad Abduh, Muhammad Sayyid Thanthawi, Abdul Wahab Khalaf, dan Mahmud Syaltut, menegaskan bahwa bunga bank hukumnya boleh dan tidak termasuk riba. Pendapat ini sesuai dengan fatwa yang dikeluarkan Majma' al-Buhus al-Islamiyyah tanggal 23 Ramadhan $1423 \mathrm{H}$, bertepatan tanggal 28 November $2002 \mathrm{M}$. Mereka berpegangan pada firman Allah subhanahu wata'ala Surat an-Nisa' ayat 29:

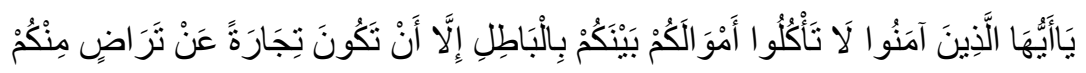

Hai orang-orang yang beriman, janganlah kamu saling memakan harta sesamamu dengan jalan yang batil, kecuali dengan jalan perniagaan yang berlaku dengan suka sama suka di antara kamu.

Pada ayat di atas, Allah melarang memakan harta orang lain dengan cara yang batil, seperti mencuri, menggasab, dan dengan cara riba. Sebaliknya, Allah menghalalkan hal itu jika dilakukan dengan perniagaan yang berjalan dengan saling ridha. Karenanya, keridhaan kedua belah pihak yang bertransaksi untuk menentukan besaran keuntungan di awal, sebagaimana yang terjadi di bank, dibenarkan dalam Islam. Di samping itu, mereka juga beralasan bahwa jika bunga bank itu haram maka tambahan atas pokok pinjaman itu juga haram, sekalipun tambahan itu tidak disyaratkan ketika akad. Akan tetapi, tambahan dimaksud hukumnya boleh, maka bunga bank juga boleh, karena tidak ada beda antara bunga bank dan tambahan atas pokok pinjaman tersebut. Di dalam fatwa Majma' al-Buhus al-Islamiyyah disebutkan:

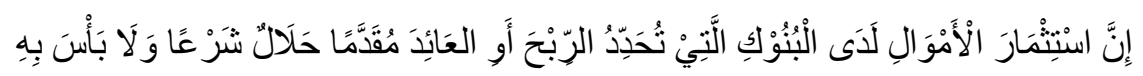

Sesungguhnya menginvestasikan harta di bank-bank yang menentukan keuntungan atau bunga di depan hukumnya halal menurut syariat, dan tidak apa-apa. (Lihat: Ali Ahmad Mar'i, Buhus fi Fiqhil Mu'amalat, Kairo: Al-Azhar Press, halaman 134-158; Asmaul Ulama al-ladzina Ajazu Fawaidal Bunuk; Fatwa Majma' Buhuts al-Islam bi Ibahati Fawaidil Masharif).

Pada Munas 'Alim Ulama NU di Bandar Lampung tahun 1992, ada tiga pendapat tentang hukum bunga bank: Pertama, pendapat yang mempersamakan antara bunga bank dengan riba secara mutlak, sehingga hukumnya adalah haram. Kedua, pendapat yang tidak 
mempersamakan bunga bank dengan riba, sehingga hukumnya adalah boleh. Ketiga, pendapat yang mengatakan bunga bank hukumya syubhat. Meski begitu, Munas memandang perlu untuk mencari jalan keluar menentukan sistem perbankan yang sesuai dengan hukum Islam. Dari paparan di atas, dapat dipahami bahwa hukum bunga bank merupakan masalah khilafiyah. Ada ulama yang mengharamkannya karena termasuk riba, dan ada ulama yang membolehkannya, karena tidak menganggapnya sebagai riba. Tetapi mereka semua sepakat bahwa riba hukumnya haram.

Terkait masalah khilafiyah seperti ini, pada prinsipnya saling toleransi dan saling menghormati serta menghargai antar pendapat harus dikedepankan. Sebab, masing-masing kelompok ulama telah mencurahkan tenaga dalam berijtihad menemukan hukum masalah tersebut, dan pada akhirnya pendapat mereka tetap berbeda. Karenanya, seorang Muslim diberi kebebasan untuk memilih pendapat sesuai dengan kemantapan hatinya. Jika hatinya mantap mengatakan bunga bank itu boleh maka ia bisa mengikuti pendapat ulama yang membolehkannya. Sedangkan jika hatinya ragu-ragu, ia bisa mengikuti pendapat ulama yang mengharamkannya. Rasul shallallahu 'alaihi wasallam bersabda:

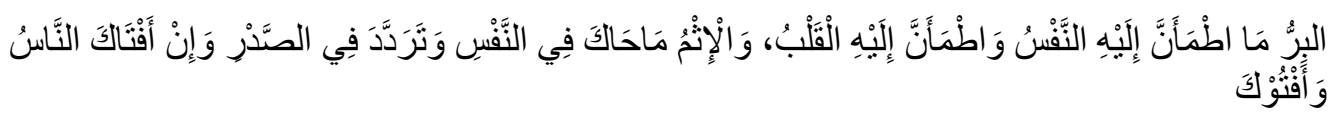

Kebaikan adalah apa saja yang menenangkan hati dan jiwamu. Sedangkan dosa adalah apa yang menyebabkan hati bimbang dan cemas meski banyak orang mengatakan bahwa hal tersebut merupakan kebaikan. (HR. Ahmad).

\section{Kontroversi Bunga Bank dikalangan Ulama}

Bunga yang diharamkan adalah Bunga yang merupakan tanggungan pada pinjaman uang, yang biasanya dinyatakan dengan persentase dari uang yang dipinjamkan. Kemudian apakah bunga termasuk riba, ada dua pendapat menurut Ibn Taymiyah dalam (Kalsum 2014, 71) ; pertama, menurut ijma ulama di kalangan semua mazhab fiqh bahwa bunga dengan segala bentuknya termasuk kategori riba. Dan kedua, pendapat yang menyatakan bahwa bunga tidak termasuk kategori riba.

Beberapa tokoh berbeda pendapat tentang riba yang diharamkan adalah riba yang bersifat adhafan muda'afatan atau berlipat ganda. Pendapat ini dikemukakan oleh Abdullah Yusuf Ali dan Muhammad Asad, yang menafsirkan riba sebagai usury yang berarti suku bunga yang lebih dari biasanya atau suku bunga yang tinggi dan bukan interest (bunga yang rendah). Adanya perbedaan penafsiran terhadap interest dan usury ini membawa konsekwensi problem konseptual yang serius sehingga timbul perbedaan pendapat terhadap kategori riba yang diharamkan. Jika merujuk kepada pendapat tafsiran Abdullah Yusuf Ali dan Muhammad Asad maka bunga bank tidak termasuk riba yang diharamkan (Chapra 2000, 223).

Muhammad Abduh, Muhammad Rashid Rida, Abd al-Wahab Khallaf, Mahmud Shaltut (Ghani 2006, 39) Mereka berpendapat bahwa riba yang diharamkan adalah riba yang berlipat ganda dan tidak termasuk riba yang kadarnya rendah. Mereka memahami sesuai dengan konteks ayat riba yang mengharamkan riba yang berlipat ganda. Sanhuri juga menganggap sebagaimana yang dikutip oleh (Saeed 1999, 43), bahwa bunga yang rendah atas modal adalah halal atas dasar kebutuhan. Ia menambahkan bahwa hukum harus menentukan batas-batas suku bunga, metode pembayaran dan total bunga yang harus dibayar. Namun pendapat terakhir ini mempunyai beberapa kelemahan, karena sepanjang sejarah tingkat (kadar) suku bunga berbeda-beda (fluktuatif) mengikuti keadaan, baik dari 
segi waktu dan tempat. Oleh karena itu sukar untuk menentukan tingkat suku bunga yang tinggi atau yang rendah berdasarkan waktu dan tempat (Ghani 2006, 40).

Pembenaran bunga atas dasar darurah dan hajjah adalah salah satu unsur penting dalam perekonomian adalah bank, yang di dalamnya terkandung sistem bunga. Bunga bank (interest) yang dianggap sama dengan riba akan sulit untuk dihentikan, karena jika bank dilarang akan menimbulkan kemacetan ekonomi. Oleh karena itu, dapat dikatakan kondisi semacam ini adalah darurat, yaitu membolehkan yang dilarang atas dasar darurat sehingga tercipta suatu sistem yang tidak menimbulkan kemacetan ekonomi (Rasyidi 1976, 40). Akan tetapi konsep ini harus melihat kondisi riilnya apakah termasuk kategori darurah dan hajah nya, semisal pada kondisi darurat tidak terpenuhi karena menyimpan uang tidak mesti di bank atau pada saat ini, lembaga keuangan syariah telah tersebarnya Lembaga-lembaga keuangan di Indonesia.

Fatwa Majelis Ulama Indonesia Nomor 1 Tahun 2004 tentang Bunga (Interest/Fa'idah) dijelaskan bahwa Bunga (interest/fa'idah) adalah tambahan yang dikenakan dalam transaksi pinjaman uang (al-qardh) yang diperhitungkan dari pokok pinjaman tanpa mempertimbangkan pemanfaatan/hasil pokok tersebut, berdasarkan tempo waktu, diperhitungkan secara pasti di muka, dan pada umumnya berdasarkan persentase. Sedangkan Riba adalah tambahan (ziyadah) tanpa imbalan (Bila 'Audh) yang terjadi karena penangguhan dalam pembayaran (Ziyadah al-Ajl), yang diperjanjikan sebelumnya (Isythuritha Muqoddiman). Adapun mengenai Bunga MUI berpendapat Praktek pembungaan uang saat ini telah memenuhi kriteria riba yang terjadi pada zaman Rasulullah SAW, yakni riba nasi'ah. Dengan demikian, praktek pembungaan uang termasuk salah satu bentuk riba, dan riba haram hukumnya. kemudian Praktek pembungaan tersebut hukumnya adalah haram, baik dilakukan oleh Bank, Asuransi, Pasar Modal, Pegadaian, Koperasi, dan Lembaga Keuangan lainnya maupun dilakukan oleh individu.

Dalam fatwa teresebut dijelaskan pula cara Bermu'amalah dengan Lembaga Keuangan Konvensional untuk wilayah yang belum ada kantor /jaringan Lembaga Keuangan Syariah, ini diperbolehkan untuk melakukan kegiatan transaksi di lembaga keuangan konvensional berdasarkan prinsip dharurat/ hajat (MUI 2004, 434-435).

\section{Norma Bagi Hasil dalam Ekonomi Islam}

Menurut bahasa bagi hasil (mudharabah) bentuk dari mufa'ala yang berasal dari kata adh-dharb fi al ardhartinya berjalan di bumi untuk menghasilkan uang. Dan disebut juga dengan qiradh dengan huruf qaf berharakat kasrah dan huruf ${ }^{\prime} a^{\prime}$ berharakat fathah tanpa tasydid yang berasal dari kata qardh yang artinya memutuskan atau memotong (Bassam 2006, 21). Adapun menurut istilah kedua kata tersebut adalah sama. Qiradh adalah pemberian dana oleh seseorang kepada orang lain untuk diolah dengan cara berniaga, dimana keuntungan yang diperoleh dibagi antara keduannya dengan syarat-syarat yang telah ditentukan oleh mereka Sedangkan mudharabah adalah akad kerja sama antara uda orang dimana yang satu memberikan sejumlah uang sedangkan yang lain memberikan jasa tenaga untuk mengolah uang tersebut. keuntungan yang dihasilkan dari usaha ini dibagi dua berdasarkan syarat yang telah mereka tentukan.

Dalam buku Biyatul Mujtahid wa Nihayatul Muqtashid kaum muslimin tidak ada perselisihan bahwa qiradh itu boleh. Pertama bahwa ini sudah ada pada zaman jahiliyah, kemudian diakui oleh Islam. Mereka juga sepakat bahwa bentuk qiradh adalah apabila seeorang menyerahkan harta kepada orang lain untuk digunakan dalam usaha perdagangan, pihak yang bekerja (diserahi uang itu) berhak memperoleh sebagian dari keuntungan harta itu. Yakni bagian yang telah disepakati sebelumnya oleh kedua belah pihak: sepertiga, seperempat, atau separuh (Said 2002, 105).

Pendapat Syakir Sula kata mudharabah diambil dari pada perkataan darb yaitu usaha di atas bumi. Dikatakan demikian karena pengelola berhak untuk berbagi hasil atas tenaga 
dan usahanya. Selain berhak atas keuntungan, dia juga berhak untuk menggunakan modal dan berusaha menjalankannya dengan arah dan tujuan yang dikehendaki. Orang-orang Madinah menyebut kontrak ini dengan muqaradah, dimana perkataan ini diambil dari kata qard yang berarti menyerahkan. Dalam hal ini pemilik modal akan menyerahkan hak atas pengelolaan modal tersebut kepada pengelola (Syakir 2004, 329).

Bagi hasil merupakan suatu langkah inovatif dalam ekonomi Islam yang tidak hanya sesuai dengan perilaku masyarakat, namun lebih dari itu bagi hasil merupakan suatu langkah keseimbangan sosial dalam memperoleh kesempatan ekonomi. Dengan demikian, sistem bagi hasil dapat dipandang sebagai langkah yang lebih efektif untuk mencegah terjainya konflik kesenjangan antara yang kaya dan si miskin di dalam kehidupan bermasyarakat. Secara teknis, konsep bagi hasil terselenggara melalui mekanisme penyertaan modal atas dasar profit and loss sharing, profit sharing atau reveneu sharing dari suatu proyek usaha dengan demikian pemilik modal merupakan partner usaha, bukan sebagai yang meminjamkan modal. Hal ini terwujud dalam bentuk kerja sama antara pemilik modal dengan pihak kedua dalam melakukan unit-unit usaha atau kegiatan ekonomi dengan landasan saling membutuhkan. Hal ini sebagaimana penelitian yang dilakukan oleh (Ahyani and Nurhasanah 2020) bahwa didalam Peran strategis ekonomi Islam khusunya di Indonesia harus mampu memberikan daya yang sangat positif bagi percepatan pembangunan ekonomi di Indonesia sendiri dengan melalui (Mudharabah) atau kemitraan berbentuk semacam usaha dengan antar pengusaha baik itu kalangan usaha kecil maupun pengusaha menengah. Pemberdayaan ekonomi Islam melalui jalut sebuah kemitraan usaha antara lembaga keuangan syari'ah dan usaha kecil menengah dengan mengembangkan kegiatan semiah pengembangan usaha sektor riil dalam bidang pertanian misalnya, atau mendirikan dan mengembangkan industri dan perdagangan serta jasa dan lembaga keuangan syari'ah. Tentu program pengembangan ini perlu diberdayakan dan dilakukan guna mendorong percepatan pembangunan ekonomi nasional dan usaha untuk meningkatkan kesejahteraan ekonomi masyarakat Indonesia. Dengan adanya system bagi hasil tentunya diharapkan mampu meningkatkan perekonomian baik skala Nasional maupun internasional yang Humanis dan berlandaskan Syari'at Islam.

\section{Prinsip-Prinsip Bagi Hasil dalam Islam}

Sistem bagi hasil merupakan sistem dimana dilakukannya perjanjian atau ikatan bersama di dalam melakukan kegiatan usaha. Di dalam usaha tersebut diperjanjikan adanya pembagian hasil atas keuntungan yang di dapat antara kedua belah pihak atau lebih (Rival and Arifin 2010, 800). Bagi hasil merupakan bentuk return atau perolehan aktivitas usaha dari kontrak investasi dari waktu ke waktu, tidak pasti dan tidak tetap pada bank Islam. Besar kecilnya perolehan kembali itu tergantung pada hasilusaha yang benarbenar diperoleh bank Islam. Dalam sistem perbankan Islam bagi hasil merupakan suatu mekanisme yang dilakukan oleh bank Islam mudharib dalam upaya memperoleh hasil dan membagikannya kembali kepada para pemilik dana shahibul mal sesuai kontrak yang disepakati di awal bersama. Besarnya penentuan porsi bagi hasil antara kedua belah pihak ditentukan kesepakatan dan harus terjadi dengan adanya kerelaan AtTarodhim oleh masing-masing pihak tanpa adanya paksaan.

Pendapatan yang dibagikan adalah pendapatan yang sebenarnya telah diterima cash basis sedangkan pendapatan yang masih dalam pengakuan accrual basis tidak dibenarkan untuk dibagi antara mudharib dengan shahibul maal. Dalam hukum Islam penerapan bagi hasil harus memperhatikan prinsip At Ta'awun yaitu saling membantu dan saling bekerja sama di antara anggota masyarakat untuk kebaikan, sebagaimana dinyatakan dalam Al Quran surat al-maidah ayat 2 : 


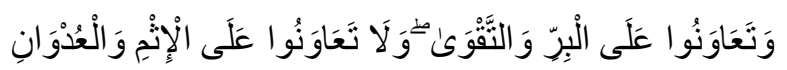

Dan tolong-menolonglah kamu dalam (mengerjakan) kebajikan dan takwa, dan jangan tolong-menolong dalam berbuat dosa dan pelanggaran.

Ada beberapa Prinsip dalam bagi hasil diantaranya sebagai berikut :

\section{Prinsip Tauhid dan Persaudaraan Tauhid dalam bagi Hasil}

Tauhid Secara harfiyah berarti satu atau esa, dalam konteks ekonomi menganjurkan bagaimana berhubungan dengan orang lain dalam hubungannya dengan Tuhannya. Prinsip ini menyatakan bahwa di belakang praktek ekonomi yang didasarkan atas pertukaran, alokasi sumber daya, kepuasan dan keuntungan, dan ada satu keyakinan yang sangat fundamental,yakni keadilan dan sosial. Dalam Islam, untuk memahami hal ini berasal dari pemahaman dan pengalaman Al-Qur'an. Dengan pola pikir demikian, prinsip tauhid dan persaudaraan terdapat azas kesamaan dan kerja sama. Konsekuensinya terdapat dari prinsip tauhid dan persaudaraan adalah pengetian yang penting dalam ekonomi Islam, yaitu bahwa apapun yang ada di langit dan di bumi hanyalah milik Allah SWT, dan bahwa dia telah menjadikannya itu sama untuk keperluan manusia dan makhluk lainnya. Manusia telah diciptakan dan diberi kepercayaan oleh Tuhan untuk menggunakan dan mendistribusikannya secara adil sumber daya Nya di bumi (Dawwabah 2006, 13).

Prinsip Kerja dalam Bagi Hasil

Prinsip ini menegaskan tentang kerja dan kompensasi dari kerja yang telah dialkukan. Prinsip ini juga menentukan bahwa seseorang harus profesional dengan kategori pekerjaan yang dikerjakan. Yaitu harus ada perhitungan misalnya "jam orang kerja" dan harus pula kategori yang spesifik bagi setiap pekerja atau keahlian. Kemudian upah dari setiap spesifikasi itu harus pula didasarkan atas upah minimum dan disesuaikan dengan pemerintahan.

\section{Prinsip Distribusi dan Kekayaan dalam Bagi Hasil}

Disini ditegaskan adanya hak masyarakat untuk mendistribusikan kekayaannya yang digunakan untuk tujuan retribusi dalam sebuah sistem ekonomi Islam adalah zakat, shadaqah, ghanimah. Hukum Islam tentang warisan mendorong untuk mendistribusikan kekayaan seseorang. Jadi retribusi pendapatan dan kekayaan secara merata berlaku terhadap Negara dan dasar ketauhitan dan persaudaraan. Tujuannya adalah untuk meningkatkan transformasi yang produktif dari pendapatan dan kekayaan nasional menjadi kesempatan kerja untuk mewujudkan kesejahteraan bagi warga Negara.

\section{Prinsip Keseimbangan dalam Bagi Hasil}

Keseimbangan merupakan nilai dasar yang bisa berpengaruh terhadap berbagai aspek kehidupan ekonomi Islam misalnya kesederhanaan, berhemat dan menjauhi pemborosan. Konsep keseimbangan ini tidak hanya perbandingan perbaikan hasil usaha yang diarahkan untuk dan akhirat saja, akan tetapi juga berkaitan dengan umum yang harus dipelihara dan keseimbangan antara hak dan kewajiban (Syaefuddin 1987, 66). Hal ini sebagaimana firma Allah Swt dalam surat al-A'raf ayat 31 sebagai berikut :

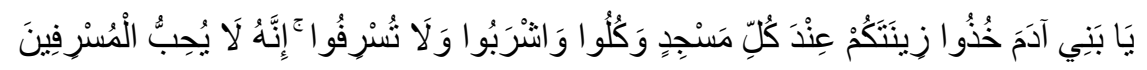

Hai anak Adam, pakailah pakaianmu yang indah di setiap (memasuki) mesjid, makan dan minumlah, dan janganlah berlebih-lebihan. Sesungguhnya Allah tidak menyukai orang-orang yang berlebih-lebihan. 


\section{Dampak Bunga Bank (Riba) terhadap Perekonomian Negara}

Negara Indonesia merupakan salah satu negara yang terbesar menganut agama Islam, namun sistem syariah baru mendapat izin untuk beroperasi pada 1 mei 1992 (27 Syawal $1412 \mathrm{H}$ ) yakni dengan didirikan Bank Muamalat Indonesia (BMI) yang digagas oleh Majelis Ulama Indonesia (MUI). Dengan telah terjadinya krisis yang diawali tahun 1997 meruapakan ujian untuk pertamakalinya sistem keuangan syariah di Indonesia. Krisis yang semula hanya berawal dari krisis nilai tukar Baht di Thailand ini menjalar menjadi krisis ekonomi, berlanjut menjadi krisis sosial, bahkan hingga krisis politik. Akhirnya pada puncaknya melumpuhkan nyaris seluruh sendi-sendi kehidupan bangsa. Krisis yang sudah berjalan pada enam bulan selama 1997 semakin memburuk dalam tempo yang relatif cepat. Sehingga pada 1 November 1997 pemerintah Indonesia mencabut izin terhadap 16 Bank karena dinyatakan tidak mampu menjalankan operasionalnya. Sementara itu Bank Muamalat Indonesia (BMI) tidak demikian halnya, BMI lolos dalam terpaan krisis tersebut. Pada dasarnya bank yang menjalankan sistem operasionalnya menggunakan bunga mengalami kerugian yang besar sementara bank yang menjalankan sistem bagi hasil (syariah) tidak demikian halnya (Mashuri 2017).

Dampak Ekonomi, dampak daripada Bunga Bank pertama adalah berdampak pada ekonomi suatu negera sebagaimana pendapat (Antoni 2001, 67) menurutnya dampak negatif dari riba dalam ekonomi adalah dampak dari inflatoir yang diakibatkan oleh bunga sebagai biaya uang. Hal tersebut disebabkan karena salah satu elemen dari penetuan harga adalah suku bunga. Semakin tinggi suku bunga, semakin tinggi pula harga yang akan ditetapkan pada suatu barang. Dalam hal ini (Agustianto 2010) dalam Riba dan Meta Ekonomi Islam dampak dari riba terhadap ekonomi diantaranya :

Pertama dalam sistem ekonomi ribawi telah banyak menimbulkan krisis ekonomi di mana-mana sepanjang sejarah Sepanjang sejarah, sejak tahun 1930 sampai saat ini akibat dari fluktuasi tingkat suku bunga, telah membuka peluang kepada para spekulan untuk melakukan spekulasi yang dapat mengakibatkan volatilitas ekonomi banyak negara.

Kedua dibawah sistem ekonomi ribawi akan muncul kesenjangan pertumbuhan ekonomi masyarakat dunia makin terjadi secara konstant, sehingga yang kaya makin kaya yang miskin makin miskin.

Ketiga dalam Suku bunga juga berpengaruh terhadap investasi, produksi dan terciptanya pengangguran. Semakin tinggi suku bunga, maka investasi semakin menurun. Jika investasi menurun, produksi juga menurun. Jika produksi menurun, maka akan meningkatkan angka pengangguran.

Keempat dalam Teori ekonomi juga mengajarkan bahwa suku bunga akan secara signifikan menimbulkan inflasi. Inflasi yang disebabkan oleh bunga adalah inflasi yang terjadi akibat ulah tangan manusia.

Dampak Sosial Kemasyarakatan, dampak social masyarakat terkait Riba dalam hal pendapatan yang didapatkan secara tidak adil. Para pengambil riba menggunakan uangnya untuk memerintahkan orang lain agar berusaha dan mengembalikan, misalnya dua puluh lima persen lebih tinggi dari jumlah yang dipinjamkan. Persoalannya, siapa yang bisa menjamin bahwa usaha yang dijalankan oleh orang tersebut nantinya mendapat keuntungan lebih dari duapuluh lima persen. Kita tahu bahwa apapun usaha yang dilakukan akan memiliki dua kemungkinan yaitu berhasil dan gagal. Namun demikian tidak demikian dengan riba. Dengan menetapkan riba dikalangan masyarakat sudah memastikan bahwa usaha yang dikelola pasti untung.

Dampak Ketahanan Perusahaan, dampak selanjutnya dari riba yaitu masuk pada ketahanan suatu lembaga atau peruahaan tertentu, Jika salah satu prinsip perusahaan merupakan going concern atau perusahaan itu akan ada selamanya maka perusahaan tersebut akan melewati berbagai kondisi ekonomi setiap waktunya, diamana cuaca kondisi 
ekonomi bisa saja dalam keadaan cerah dan bisa juga sangat ekstrim di waktu yang tertentu, oleh karena itu hanya perusahaan yang punya daya ketahananlah yang akan tetap bertahan. Menyadari akan keadaan tersebut maka perusahaan akan senantiasa mencari cara dan skema bertahan dalam menghadapi berbagai macam kondisi ekonomi, maka pertanyaanya adalah seberapa jauhkah bunga berpengaruh terhadap ketahanan perusahaan. Permasalahan di atas, sebenarnya, tidak pernah terjadi jika ekonomi Islam diadopsi dalam sistem ekonomi negara. Karena nilai uang tidak akan dipengaruhi oleh perbedaan tingkat bunga riel, sebab ekonomi Islam tidak mengenal sistim bunga (riba). Inilah yang menyebabkan nilai uang dalam ekonomi tanpa bunga tidak mengalami volatilitas yang membahayakan. Di Indonesia, sistem ekonomi ribawi telah menimbulkan dampak yang sangat buruk agi perekonomian Indonesia.

\section{Pendapat Ulama Tentang Bagi Hasil}

Jumhur ulama berpendapat bahwa kebolehan bagi hasil. Menurut pendapat mereka, bagi hasil ini dikecualikan oleh as-sunnah dari larangan menjual sesuatu yang belum terjadi, dan dari sewa menyewa yang tidak jelas. Hukum sahnya bagi hasil menurut Imam Malik, bahwa akad bagi hasil itu merupakan akad yang mengikat (lazim) dengan kata-kata, bukan dengan perbuatan. Tidak demikian halnya dengan qiradh yang baru bisa terjadi (terwujud) dengan adanya perbuatan (pekerjaan), bukan dengan kata-kata. Imam Malik juga berpendapat bahwa akad bagi hasil merupakan akad yang dapat mendatangkan orang yang bisa dipercaya untuk bekerja, mana kala ahli waris (dari orang yang menagdakan akad) tidak dapat dipercaya. Orang yang dipercaya itulah yang ahrus bekerja, jika ahli waris menolak harta peninggalannya (Rusyd 1990, 250).

Imam Syafi'i berpendapat bahwa apabila seseorang menyerahkan harta kepada orang lain sebagai modal usaha mudharabah (bagi hasil), namun pemilik modal tidak memerintahkan pengelola untuk mengutangkan hartanya dan tidak pula melarangnya, kemudian pengelola mengutangkannya dalam suatu penjualan atau pembelian, maka semuanya adalah sama dimana pengelola harus mengganti rugi, kecuali bila pemilik modal merestuinya atau ditemukan bukti bahwa pemilik modal mengijinkan pengelola untuk melakukan hal tersebut. Jika seseorang memegang harta sebagai modal usaha mudharabah (bagi hasil), lalu ia menggunakan harta dalam transaksi tidak tunai dan pemilik harta tidak memerintahkan dan tidak pula melarangnya (yakni dengan perkataannya), maka jika terjadi sesuatu pada harta itu, pihak pengelola harus mengganti rugi kepada si pemilik modal.

Abu Hanifah berpendapat bahwa pengelola modal dalam usaha mudharabah tidak perlu mengganti rugi. Apa saja yang ia pinjamkan adalah sesuatu yang diperbolehkan. Pendapat ini menjadi pandangan Abu Yusuf. Sedangkan Ibnu abu Laila berpendapat bahwa pengelola modal harus mengganti rugi kecuali ia dapat mengajukan bukti bahwa pemilik harta telah mempekenankannya melakukan transaksi tidak tunai. Tapi bila pengelola memberikan modal kepada orang lain sebagai hutang, maka ia harus mengganti rugi menurut pendapat keduanya, sebab utang-piutang tidak masuk bagian usaha mudharabah (Abdullah 2006, 137).

Ibnu Munzir berpendapat bahwa para ulama sepakat bahwa pekerja harus mensyaratkan kepada pemilik modal bahwa ia mendapatkan sepertiga atau setengah dari laba, atau berdasarkan kesepakatan keduanya setelah hal tersebut diketahui bagianbagiannya. Seandainya ditetapkan untuknya semua laba, sejumlah dirham yang telah diketahui sebelumnya atau bagian yang tidak diketahui, maka kongsi ini tidak sah (alfauzan 2005, 468).

Istilah praktek mudarabah pada intinya adalah I Believe, I Trust yaitu bermakna saya percaya atau saya menaruh kepercayaan. Perkataan bagi hasil yang artinya kepercayaan (trust), berarti lembaga badan usaha selaku sahibul 
mal menaruh kepercayaan kepada seseorang untuk melaksanakan amanah yang diberikan. Dana tersebut harus digunakan dengan benar, adil, harus disertai dengan ikatan dan syarat-syarat yang jelas dan saling menguntungkan bagi kedua belah pihak (Muhammad 2001, 27).

Konsep bagi hasil dan bagi rugi yang ditawarkan Islam adalah sistem mudarabah atau disebut dengan konsep profit sharing dan revenue sharing di mana untung dan rugi dari sebuah kerjasama ditanggung oleh semua pihak yang bekerja sama. Profit sharing menurut etimologi indonesia adalah bagi keuntungan. Dalam kamus ekonomi diartikan dengan pembagian laba. Profit Sharing menurut istilah merupakan perbedaan yang timbul ketika total pendapatan (total revenue) suatu perusahaan lebih besar dari biaya total (total cost). Istilah lain daripada profit sharing yaitu perhitungan bagi hasil didasarkan kepada hasil bersih dari total pendapatan setelah dikurangi dengan biaya-biaya yang dikeluarkan untuk memperoleh pendapatan tersebut. Pada perbankan syariah istilah yang sering dipakai adalah profit sharing, di mana hal ini dapat diartikan sebagai pembagian antara untung dan rugi dari pendapatan yang diterima atas hasil usaha yang telah dilakukan (Yunus 2009, 90).

Prinsip lainnya yaitu revenue sharing, ini yang secara bahasa revenue bermakna uang masuk, pendapatan, atau income. Didalam istilah perbankan revenue sharing berarti suatu proses bagi pendapatan yang dilakukan sebelum memperhitungkan biaya-biaya operasional yang ditanggung oleh bank, biasanya pendapatan yang di distribusikan hanyalah pendapatan atas investasi dana, dana tidak termasuk komisi atau jasa-jasa yang diberikan oleh badan usaha karena pendapatan tersebut pertama harus dialokasikan guna mendukung biaya operasional badan usaha (Karim 2004, 45). Artinya dalam hal ini terkait pembagian dana terhadap pengelola atau mudarib atas pendapatanpendapatan yang diperoleh oleh badan usaha tanpa menunggu pengurangan-pengurangan atas pembiayaan-pembiayaan yang dikeluarkan oleh badan usaha dalam pengelolaan dana yang diamanatkan oleh pengelola tertentu, disatu sisi pelaksanaan revenue sharing ini bertentangan dengan prinsip bagi hasil itu sendiri, karena dalam prinsip bagi hasil yang seharusnya investor bertanggung jawab atas dana yang diamanatkannya, dengan demikian hal ini memiliki andil dalam hal pengelolaan dananya, bahkan jika terjadi kerugian dalam usaha maka Sahibul mal atau insvestor harus ikut menanggung kerugiannya pula.

Contoh misalnya Pola bagi hasil mudarabah usaha di BUMP Pondok Pesantren Al Luqmaniyyah Kota Yogyakarta, Daerah Istimewa Yogyakarta yang terdiri dari beberapa badan usaha tidak semuanya sama dalam menerapkan pola bagi hasil usaha. Ada beberapa badan usaha di BUMP yang menerapkan pola bagi hasil yang berupa revenue sharing yang berarti bagi hasilnya sebelum dikurangi biaya operasional dari usaha tersebutdan ada juga yang menerapkan pola bagi hasil usaha profit sharing dimana bagi hasilnya setelah dikurangi biaya operasional dari badan usaha tersebut. Dalam perspektif hukum bisnis syari'ah pola bagi hasil semacam ini terkait akad mudarabahnya sesuai dengan prinsip syari'ah. Hal ini terlihat dari terpenuhinya syarat dan rukun, kesesuaian dengan prinsip-prinsip Islam tentang pengaturan ekonomi (muamalah) dan etika bisnis syariah. Praktek mudarabah yang dilakukan pada BUMP didasarkan pada kerjasama dan bagi hasilnya seusai dengan kesepakatan awal antara pengelola dan shahibul mal agar terhindar dari riba dan hal-hal yang samar atau gharar (Putra 2018).

\section{KESIMPULAN}


Berdasarkan pembahasan di atas dalam kaitanya permasalahan Konsep dalam Norma Riba, Bunga Bank, dan Bagi Hasil di Kalangan Ulama Ulama dulu dan sekarang tersebut di atas, maka dapat disimpulkan beberapa point diantaranya :

1. Norma Riba dalam Ekonomi Islam merupakan masalah khilafiyah begitupun hukum Bunga Bank pada prinsipnya saling toleransi dan saling menghormati serta menghargai antar pendapat harus dikedepankan. Sebab, masing-masing kelompok ulama telah mencurahkan tenaga dalam berijtihad menemukan hukum masalah tersebut, dan pada akhirnya pendapat mereka tetap berbeda. Karenanya, seorang Muslim diberi kebebasan untuk memilih pendapat sesuai dengan kemantapan hatinya. Jika hatinya mantap mengatakan bunga bank itu boleh maka ia bisa mengikuti pendapat ulama yang membolehkannya. Sedangkan jika hatinya ragu-ragu, ia bisa mengikuti pendapat ulama yang mengharamkannya.

2. Norma bagi hasil dalam Ekonomi Islam suatu langkah inovatif dalam ekonomi Islam yang tidak hanya sesuai dengan perilaku masyarakat, namun lebih dari itu bagi hasil merupakan suatu langkah keseimbangan sosial dalam memperoleh kesempatan ekonomi. Dengan demikian, sistem bagi hasil dapat dipandang sebagai langkah yang lebih efektif untuk mencegah terjainya konflik kesenjangan antara yang kaya dan si miskin di dalam kehidupan bermasyarakat. Secara teknis, konsep bagi hasil terselenggara melalui mekanisme penyertaan modal atas dasar profit and loss sharing, profit sharing atau reveneu sharing dari suatu proyek usaha dengan demikian pemilik modal merupakan partner usaha, bukan sebagai yang meminjamkan modal. Hal ini terwujud dalam bentuk kerja sama antara pemilik modal dengan pihak kedua dalam melakukan unit-unit usaha atau kegiatan ekonomi dengan landasan saling membutuhkan. Ada beberapa prinsip dalam bagi hasil diantaranya Prinsip Keseimbangan, Prinsip Distribusi dan Kekayaan, Prinsip Kerja, Prinsip Tauhid dan Persaudaraan.

3. Dampak Bunga Bank (Riba) terhadap Perekonomian Negara diantaranya berdampak dari terhadap beberapa sector diantaranya Dampak Ekonomi, Semakin tinggi suku bunga, semakin tinggi pula harga yang akan ditetapkan pada suatu barang. Dampak Sosial Kemasyarakatan, dampak sosial masyarakat terkait Riba dalam hal pendapatan yang didapatkan secara tidak adil. Dampak Ketahanan Perusahaan, hanya perusahaan yang punya daya ketahananlah yang akan tetap bertahan.

\section{DAFTAR PUSTAKA}

Abdullah, I. S. (2006). Terjemahan Mukhtashar Kitab Al Umm fi al Fiqh. Jakarta: Pustaka Azzam.

Agustianto. (2010). Riba dan Meta Ekonomi Islam.

al-Arabi, I. (1957). Ahkam Al-Qur'an, juz 1. Mesir: Isa al-Halaby.

al-fauzan, S. (2005). Fiqh sehari-Hari. Jakarta: Gema Insani Press.

Al-Jaziri, A. (t.t). Kitab al-Fiqh ala Madzahib al-Arba'ah. Beirut: Dar al-Fikr.

al-Jurjani, A. b. (t.t). Kitab al-Ta'rifat. Beirut: Dar al-Kutub al-Islamiyyah.

al-Nawawi. (t.t). al-Majmu', jilid IX. Beirut: Dar al-Fikr.

Al-Qardhawi, Y. (2002). Bunga Bank Haram. Jakrta: Media Eka Sarana.

al-Qurtubi, A. a.-W. (1981). Bidayah al-Mujtahid wa an-Nihayah al-Muqtasid Juz 2. Beirut: Dar al-Ma'rifah.

al-Shabuni, M. A. (t.t). Rawa;i al-Bayan Tafsir Ayat Ahkam min al-Qura'n, jilid 1. Beirut: Dar al-Fikr.

Antoni, M. S. (2001). Bank Syariah dari teori ke praktek. Jakarta: Gema Insani.

Antonio, M. S. (2001). Bank Syari'ah dari Teori ke Praktek. Bandung: Gema Insan. 
Asshiddiqie, J. (2011). Perihal Undang-Undang. Jakarta: Rajawali Pers.

Bakar, A. (2018). Riba Dalam Muamalah (Studi Terhadap Hadis-Hadis Riba). Yogyakarta: Fakultas Syariah Dan Hukum UIN Sunan Kalijaga.

Bassam, A. b. (2006). Syarah Bulughul Maram. Jakarta: Pustaka Azzam.

Chapra, M. U. (2000). The Future of Economics: An Islamic Perspective. Kenya: The Islamic Foundation.

Dawwabah, M. A. (2006). Meneladani Keunggulan Bisnis Rasulullah. Semarang: PT. Pustaka Rizki Putra.

Ghani, A. M. (2006). Dinamisme Kewangan Islam di Malaysia. Kuala Lumpur: University Malaya.

Hadi, A. S. (1993). Bunga Bank dalam Islam (terj). Surabaya: Al-Ikhlas.

Karim, A. (2004). Bank Islam: Analisis Fikih dan Keuangan. Jakarta: Raja Grafindo Persada.

Muhammad. (2001). Teknik Perhitungan Bagi Hasil di Bank Syariah. Yogyakarta: UII Press.

MUI. (2004). Fatwa Majelis Ulama Indonesia Nomor 1 Tahun 2004 Tentang Bunga (Interest/Fa'idah). Jakarta.

Muslich, A. W. (2013). Fiqh Muamalat. Jakarta: Amzah.

Nasional, P. B. (2008). Kamus Bahasa Indonesia. Jakarta.

Rasyidi, M. (1976). Hukum Islam dan Pelaksanaannya dalam Sejarah. Jakarta: Bulan Bintang.

Rival, V., \& Arifin, A. (2010). Islamic Banking. Jakarta: PT. Bumi Aksara.

Rusyd, I. (1990). Terjemahan Bidayatul-Mujtahid. Semarang: Asy-Syifa.

Said, I. G. (2002). Terjemahan Bidayatul Mujtahid wa Nihayatul Muqtashid. Jakarta: Pustaka Amani.

Shihab, M. Q. (1998). Wawasan Al-Qur'an; Tafsir Maudhu'i atas berbagai Persoalan Umat. Bandung: Mizan.

Syaefuddin. (1987). Ekonomi dan Masyarakat dalam Perspektif Ekonomi Islam. Jakarta: CV. Rajawali Press.

Syakir, M. (2004). Asuransi Syariah (Life and general): Konsep dan sistem Operasional. Jakarta: Gema Insani.

Yunus, J. L. (2009). Manajemen Bank Syariah Mikro. Malang: UIN Malang Press.

Ahyani, H., \& Nurhasanah, E. (2020). PERAN STRATEGI POLITIK ISLAM TERHADAP PEREKONOMIAN DI INDONESIA. Mutawasith: Jurnal Hukum Islam, $18-43$.

Kalsum, U. (2014). RIBA DAN BUNGA BANK DALAM ISLAM (Analisis Hukum dan Dampaknya Terhadap Perekonomian Umat). Jurnal Al- 'Adl IAIN Kendari Vol. 7 No. 2, Juli .

Mashuri. (2017). Analisis Dampak Bunga Bank (Riba) Bagi Perekonomian Negara. IQTISHADUNA: Jurnal Ilmiah Ekonomi Kita , 98-107.

Putra, Y. H. (2018). TINJAUAN HUKUM ISLAM TERHADAP POLA BAGI HASIL (MUDARABAH) PADA BUMP (STUDI KASUS DI PONDOK PESANTREN ALLUQMANIYYAH UMBULHARJO YOGYAKARTA). Al-Mazahib: Jurnal Pemikiran Hukum .

Saeed, A. (1999). Islamic Banking and Interest, Saeed, Abdullah. Islamic Banking And Interest: A Studi of Prohibition Riba and its Contemporary Interpretation. (Leiden-New York: E.J. Brill, 1996), h. 43-44. Leiden: Brill 